memory, for I often in imagination fight again my battles with halibut and skate, lobster and cod, and the words "sea fisheries" have not altogether lost their charm; but I confess I wholly overlooked Prof. Newton's interesting letter on the subject, and turned back the file of NATURE and read the Ietter in connection with Mr. Holdsworth's. The theory of the former appears to me to be the correct one; the Atlantic sea fishery is being gradually played out.

I doubt whether we can 'anywhere along its extensive coast now meet with "shoals" of mackerel or "schools" of herring several miles in breadth, forming a mass of so compact a nature that small vessels had almost as much difficulty in getting through them as Sir George Nares had in getting through the so-called palæocrystic ice, or hear of single hauls of $\mathbf{I}, 000$ barreis! And yet such was possible not twenty-five years ago.

The great mischief is done, certainly in America, by trawling. This must he evident if one will but consider the modus operandi, by which the female fish are captured just before they have deposited their spawn, a few thousand fish so taken representing the non existence of many millions. The subject has received the most serious attention of the Canadian Government, and has by it been brought under the notice of the United States and French authorities.

Mr. Holdsworth appears very much amused to find that Prof. Newton has discovered a use for dogfish over and above his own instance, in which it served as "salmon" for the Preston weavers. But as we have never heard that the fishermen of Morecambe Bay were charged with feloniously administering a poison to the said weavers, we must conclude that dogfish is a wholesome, but jerriaps not a toothsome, article of food.

Mir. Holdsworth says that with this exception he has never heard of a case in which "the hated dogfish was not knocked on the head and thrown overboard whenever there wras a chance of so doing." I can tell him one. Along the American coast the dogfish is certainly knocked on the head, but the fishermen there know its value too, well to throw it overboard; they keep it, and it yields an oil ; and of the many millions of gallons of "fish-oil" in the returns, "dog-oil" forms no inconsiderable portion.

There can be no doubt that the American fishermen, if they had had their say in creation, would have vetoed dogfish; but as they had not, they came to the conclusion that there was doubtless some wise purpose even in that creature: a thom in the flesh to try their tempers and their nets, but one which they forced to bear fruit.

If it is true that the nets of the Donegal fishermen. in 1875 were constantly full of dogfish, and they driven to their wits' end. I hope some Donegal reader of NATURE will kindly read them this letter ; it may be the means of opening up a glorious future for Ireland. Perhaps too some Lancashire reader will give the Morecambe Bay fishermen a hint, in case the Blackburn weaver should hereafter have a surfeit of "salmon," and those practical jokers' occupation be gone.

May I in conclusion be allowed to dissent from Prof. Baird's plural of "alewife?" He calls it "alewives." There is nothing of the meaning of wife in the word. This species of herring, which usually goes by the name of gaspereau, is also called alewife, which is a corruption of the Indian word for a fish, aloof. The plural, I think, should be "alewifes," B. G. JENkins

Dulwich, December 18

\section{Sense of Hearing in Birds and Insects}

I do not know whether ornithologists are acquainted with the peculiar manner in which curlews frequently obtain their food on sandy flats which have been left bare by the tide. The birds force their long bills into the wet sand as far as the nostrils, and then again withdraw it, leaving a small hole, which, when probed, is found to be only just large enough to have taken in the bill. The animal, therefore, can only have made a single prolonged push without adding any lateral or exploring movements of the bill, as birds which feed in mud may be ooserved to do. Now it cannot be supposed that curlews adopt this mode of feeding without obtaining from it some degree of profit. Neither can it be supposed that they make their thrusts into the sand at random ; for, their bills being so pointed and slender, the birds would usually require to make a vast number of ineffectual thrusts before they happened to hit upon a worn or other edible object. The question therefore is, How do the birds know the precise spots where their victims lie buried in the sand? That this knowledge is not derived by sight $I$ am quite sure, for I have repeatedly observed innumerable curlew marks of the kind described occur. ring on tracts of sand which, in virtue of their high level, presented a perfectly smooth and uniform surface. I can therefore only suppose that the birds are guided in their probings by their sense of hearing. Doubtless it is difficult to believe that this sense is so delicate and precise as to enable the curlew to perceive so exceedingly slight a sound as that which must be caused by the movement, say, of a small worm at a distance of ten or twelve inches from the surface of the sand, and at the same time to localise the exact spot beneath the surface from which so slight a sound proceeds. I cannot see, however, that any other explanation is open, and perhaps the one now offered may not seem so incredible if we remember the case of the thrush. No one, I think, can observe this bird feeding and doubt that it finds its worms and grubs almost exclusively by the sense of hearing. And if the distance which it runs between successive pauses for listening represents-as we cannot but suppose it must-the diameter of the circle within which this bird is able to hear the movements of a worm, I think that the hypothesis I have just advanced with regard to the curlew ceases to be improbable.

It seems worth while to add a few words with respect to the sense of hearing in insects. So far as I am aware, the occurrence of such a sense in this class has never been actually proved, although on a friori grounds there can scarcely be any doubt concerning the fact of some insects being able to hear; seeing that in so many species stridulation and other sounds are made during the season of courtship. In the case of moths, however, I believe that sounds are never emitted-except, of course, the death's-head. It therefore becomes interesting to observe that an auditory sense is certainly present in these insects. Several kinds of moth have the habit of gently, though very rapidly, vibrating their wings, while they themselves are at rest on a flower or other surface. If, while this vibrating movement of the wings is going on, the observer makes a sudden shrill note with a violin or fife, \&c., the vibrating movement immediately ceases, and sometimes the whole body of the insect gives a sudden start. These marked indications of hearing I found invariably to follow a note with a high pitch, but not a note with 2. low one.

George J. Romanes

\section{"Towering" of Birđs}

I HAVE read Mr. Romanes' communication on the "towaring" of grouse and partridges with much irterest. As he requests further information, may I be permitted to contribute the following :- I once observed a pheasant which, after being shot, flew apparently untouched for about one hundred yards, then towered ten or fifteen yards, and fell dead. As a rule birds that have towered are picked up dead, as Mr. Romanes states; but such is not invariably the case. A correspondence took place in the Field some weeks since in answer to the question: "Do towered birds ever rise again," and several replies were elicited in the affirmative. The conclusion warranted by that correspondence seemed to be that towering arises from at least two distinct kinds of injury. In the first, the common form, the bird is struck in the $b a c k$, and is always found precisely where marked down. It seems to me that in this kind of towering the perpendicular flight may be attributed to a cause perhaps other than, or at all events additional to, pulnonary hremorrhage. I consider that hæmorrhage is a necessary factor, and Mr. Romanes makes out a very strong case in favour of its being into the lungs. That the movements of the wings are convulsive, and the explanation of the towering, I am not inclined to dispute, but I think it has yet to be proved that the convulsive flapping of wings (the directing power of the brain being in abeyance) always produces perpendicular and never merely erratic flight. Every towering bird acts in a precisely similar way. Are we to take it for granted that in asphyxia it is only certain sets of muscles, and these always in the same and to an equal degree, that are spasmodically affected? I have noticed that a towering bird very often has his legs hanging straight down (I do not allude to those cases where they are palpably mutilated), and it strikes me as being likely that paralysis of the legs and lower part of the back may have something to do with the flight being upward. A man who has paraplegia always complains that he cannot move his legs because they are so heavy. This sensation would doubtless be felt by a bird paralysed behind, and this, in addition to the loss of its steering apparatus and the co-operating contractions of the posterior muscles, would produce a loss of balance with much the same effect as though the after parts had really become disproportionately heavy. I have no desire to be 